\title{
Neotropikey - um esforço internacional no sentido de abrir portas virtuais para o conhecimento das plantas neotropicais
}

\author{
Neotropikey - an international effort to construct a gateway to \\ knowledge resources on neotropical plants
}

\author{
William Milliken \\ Bente Bang Klitgaard \\ Amelia Barbosa Baracat \\ Nicholas D.J. Hind \\ Royal Botanic Gardens em Kew, Reino Unido
}

\begin{abstract}
Resumo: $\mathrm{O}$ acesso rápido às informações sobre diversidade botânica e ecologia, o planejamento de medidas de conservação eficientes, a valorização e a manutenção dos serviços do ecossistema e a promoção de estilos de vida sustentáveis no neotrópico são hoje em dia assuntos extremamente urgentes e importantes. A identificação correta das plantas é fundamental para todos esses processos e continua a ser um desafio para a maioria dos usuários desse tipo de informação, com grande parte da literatura taxonômica ainda relativamente inacessível e dedicada a um público extremamente especializado. Com a finalidade de tornar essa informação disponível para um maior número de pessoas, a Neotropikey fornece ferramentas on-line para identificação de plantas neotropicais, atualmente incluindo uma chave eletrônica de acesso múltiplo e resumos ilustrados das famílias de angiospermas na região. Trata-se de um projeto colaborativo, liderado pelo Royal Botanic Gardens em Kew (Reino Unido), que envolve taxonomistas de toda a América Latina, bem como de outros países do mundo. Entre os produtos futuros, estão previstas chaves a nível genérico e descrições de gênero interativas. O presente artigo descreve os resultados do projeto, incluindo as estratégias e os métodos utilizados para atingir esta fase, assim como os desafios enfrentados na preparação deste tipo de recurso e as oportunidades para colaboração e desenvolvimento que serão acarretadas a partir deste momento.
\end{abstract}

Palavras chaves: Neotropical. Plantas. Angiospermas. Famílias. Identificação. Chaves. Acesso múltiplo. Internet.

Abstract: Understanding botanical diversity and ecology, planning effective conservation measures, valuing and maintaining ecosystem services and promoting sustainable livelihoods are now more important in the Neotropics than ever before. Accurate identification of plants is fundamental to all these processes and continues to pose a challenge with much of the taxonomic literature still relatively inaccessible and targeted towards specialist users. To help address this issue, Neotropikey is providing online tools for the identification of Neotropical flowering plants. These currently include a "multi-access" electronic key and illustrated synopses of the plant families of the region. The project, led by the Royal Botanic Gardens, Kew (UK), is based around a collaboration involving taxonomic specialists from across Latin America as well as other parts of the world. Future products will include keys to genus level, and interactive generic descriptions. This paper describes the outcomes of the project, the methods and 
approaches behind it, some of the challenges faced in developing such resources, and the opportunities for future development and collaboration.

Keywords: Neotropics. Plants. Families. Identification. Keys. Multi-access. Internet.

\section{INTRODUCTION}

The last decade has witnessed an explosion in the speed and use of the internet. This has been transmitted into biodiversity studies in general and plant taxonomic initiatives more specifically, with initiatives such as the European Distributed Institute of Taxonomy (EDIT), Planetary Biodiversity Inventories (PBI) and Encyclopedia of Life (EOL). With the release of software such as MEKA (Multiple-Entry Key Algorithm), Descriptive Language for Taxonomy (DELTA), LUCID and Scratchpad, we have entered an era of cyper-taxonomy and cyper-bioinformatics (e.g. WHEELER et al., 2004; WHEELER, 2008 and papers therein).

The recent completion of the Brazilian Vascular plants checklist, with 40,989 currently recorded species (FORZZA et al., 2010), highlights the major challenge in the accurate identification of Neotropical plants. Continuing advances in molecular systematics have resulted in significant shifts in family and genus concepts (e.g. APG II, 2003; APG III, 2009), adding further complexities to the use of outdated taxonomic literature for plant identification. With unprecedented levels of threat to, and loss of, Neotropical vegetation, our ability to understand the botanical diversity and ecology of this globally important region, and to take effective action to ensure its conservation and its continued provision of ecosystem services and sustainable livelihoods, is more important than ever.

Neotropikey was set up to deliver online plant identification resources, available to all at no cost. Based at the Royal Botanic
Gardens, Kew, the project has drawn together an international network of contributors including many from Latin America. The first phase, launched in 2010, aimed to produce an online, multiaccess key to Neotropical flowering plants, and accompanying individual family web-pages. Where possible these pages include colour-illustrated information on the characteristics, distribution, status, delimitation and important literature for each family, also incorporate dichotomous keys and other tips for identification to genus level. Many of these dichotomous keys were formerly only available in relatively inaccessible parts of the botanical literature, and this is the first time that they have been made accessible via the Internet.

Neotropikey has developed the first multi-access key focused specifically on the complete range of Neotropical flowering plant families. The obvious benefit of multi-access keys is their ability to cater for differing circumstances (flowering, fruiting or even sterile specimens) and differing levels of botanical knowledge. The advantage of delivering such resources online is that they can, unlike printed resources, remain flexible, allowing adjustment to reflect the availability of new information, the input of new specialists, and shifts in taxonomic and systematic thinking. They also allow low-cost delivery of large numbers of colour images to support the identification process, and links to existing and emerging web-based resources.

The disadvantage, perhaps, is that web-based resources still tend to be rated lower than hard-copy publications in 
assessments of scientific productivity, providing little incentive for scientists to make major efforts to develop them. Furthermore, plant identification resources ideally should be usable in the field, where access to the Internet is often limited or absent. Electronic resources are not currently a substitute for printed manuals and field guides; they complement them. Nonetheless with the rapid development of mobile phone applications and memory, it will not be long before such resources are widely available on portable handsets. In the meantime, the provision of the key and family synopses in $\mathrm{CD}$ format will to some degree bridge this divide.

\section{METHODOLOGY}

The first phase of the development process involved taxonomic/systematic analysis, software selection, establishment of key characters and character states, and development of a standard format for family profiles. We defined the taxonomic framework of the 316 Neotropical Angiosperm families using the APG II system (2003), combined with MAAS \& WESTRA (2004) and incorporating the most recent family circumscriptions of Monocotyledon families following the APG III system (2009). Whilst the principal taxonomic focus of the key is native plants, we have also endeavoured to include taxa that are most commonly cultivated or naturalised. However, it should be noted that not all cultivated or naturalised taxa have been included. The geographical scope was taken to be the families occurring in the Americas between the Tropics of Capricorn and Cancer, although within their treatments some contributors have chosen to include taxa that do not occur within this strictly definined zone. For selection of characters we began with the list developed by the team who created the electronic DELTA key to Malesian Flowering Plant families and customized these to fit the Neotropikey context. Throughout the testing period we have, however, refined, reworded and in some cases recircumscribed these characters, adjusting scores accordingly.

On the basis of consultation with researchers working in this field, Lucid was selected for the multi-access key and Factsheet Fusion, its 'sister' software, for the family profiles. Lucid is one of the most advanced programmes currently available for such applications and continues to be developed and improved; it is relatively simple to use and is flexible.

We contacted international taxonomic specialists on Neotropical plant families and received contributions from more than 100 taxonomists. Forty-five of these are associated with universities and research institutions in Latin America. These specialists provided coding of their specialist families (for the key) plus text and images for the synopses, using standard data sheets with drop-down boxes for ease of use, and protocols for image format, text composition, copyright assignment, etc. The remaining c. 200 families were coded in-house by the Kew Tropical America team.

In order to provide a rapid return to contributors and to facilitate the process of testing and refinement, the family synopses were made available online as soon as they had been processed. Contributors and other representatives of target user groups were invited to test the prototype products and respond on standard feedback forms designed to link usability with level of experience and botanical knowledge. 


\section{CHALLENGES AND SOLUTIONS IN PROJECT DEVELOPMENT}

In developing Neotropikey we have met with various challenges and have learned several lessons. We have, for example, had difficulties with the speed of internet delivery of the key (this remains an issue for slower internet connections). As exported from the standard Lucid software for web deployment, the key requires a Java 'applet' to be downloaded automatically by the user every time the page is accessed, reducing the speed of its delivery. Deploying via Lucid's web server software has the advantage of not requiring this download, but currently its user interface is less sophisticated and adaptable than with the former approach. As Internet speeds increase globally this will become a less significant problem, but meanwhile it may prove that alternative ways of delivering the key would be better suited to the purpose.

Whilst drawing on a large network of international contributors has brought many advantages, including access to specialist knowledge and resources, inkind contributions and the establishment of broad project ownership, it has not come without its challenges. These have included the need to resolve differing interpretations of key characters and family synopsis headings, varying taxonomic views (sometimes conflicting between specialists in systematically related taxa), language issues and, in some cases, the inability of contributors to deliver according to agreed schedules or guidelines. All of this has, as with any floristic project, produced a very heavy workload of coordination, monitoring, editing and communication coupled with repeated updates of the data. Although essential for success, this workload provides its own challenges where limited human resources are available.
Whilst we had hoped to engage contributors in the process of testing and finalising the key, very few took part in these activities. Nevertheless we feel that the advantages of this approach outweigh the disadvantages, and intend to work in a similar manner during the second phase of the project.

Whilst our aim is to develop a resource that can be accessible and useful for botanists and non-botanists alike, this always provides a challenge and is only partially achievable. Part of the difficulty lies with botanical terminology which, whilst generally obscure for non-specialists, is hard to avoid if one is to achieve the level of resolution required for identification in a highly diverse region. To some degree we have addressed this by offering different levels of detail within the key, e.g. (at the simpler level) leaves opposite or alternate, or (at the more complex level) alternatespiral, opposite-decurrent etc. Accessibility to non-specialists is also improved by the availability of a glossary.

Our intention to illustrate the key and synopses with live plant images has been greatly helped by the rapid acceleration of digital photography, although data management has not always kept pace with productivity in this field. Obtaining accurately named images with guaranteed copyright access can therefore be challenging, and image handling and processing time-consuming. In the case of a few of the more obscure Neotropical families we have not been able to find images at all.

In theory the multi-access key approach facilitates the inclusion of field characters such as exudates, smells etc., usually absent from taxonomic treatments, making it more useful for ecological and ethnobotanical studies and the identification of sterile vouchers. However, botanists accustomed to working with herbarium specimens are not always familiar with these characters and they are not always available in the 
taxonomic literature. Given that the key software works on the basis of the exclusion of taxa not displaying such characters, their scoring requires a conservative approach where any level of doubt exists, thus making these characters less useful within the key.

\section{THE NEXT PHASE}

Neotropikey is an ongoing programme that will continue to develop resources for plant identification in the Neotropics, and to engage an increasingly wide circle of taxonomists. In addition, we also hope to draw more deeply on the vast knowledge of experts in field identification, in order to improve the key's efficacy for identifying sterile specimens. The next phase of the project will include two distinct activities: (1) improvement and expansion of the existing resource on the basis of feedback and specialist/non-specialist input, and (2) development of genus-level identification resources. Specialists will be invited to produce their own genuslevel (or, in the case of small families, species-level) interactive LUCID keys, drawing on a series of 'core' characters and adding taxon-specific characters where necessary. These keys will be linked from the family synopses as well as indexed separately, expanding the reach and scope of Neotropikey. Genus-level information will be developed by the contributors directly using a shared online platform such as the EDIT Scratchpads (2010).

\section{AGRADECIMENTOS}

This project represents a collaborative effort between a great many scientific and technical contributors, too numerous to list here. A full list of acknowledgements is available on the Internet at: <http:// www.kew.org/science/tropamerica/ neotropikey_contributors.htm>.

\section{REFERENCES}

APG II. Angiosperm Phylogeny Group. An update of the Angiosperm Phylogeny Group classification for the orders and families of flowering plants: APG II. Bot. J. Linnean Soc., n. 141, p. 399-436, 2003.

APG III. Angiosperm Phylogeny Group. An update of the Angiosperm Phylogeny Group classification for the orders and families of flowering plants: APG III. Bot. J. Linnean Soc., n.161, p. 105-121, 2009.

CBIT. Centre for Biological Information Technology. LUCID software. Available: <http:/ / www. lucidcentral.com/>. Accessed: 14th Jul. 2010.

DALLWITZ, M. J. Description language for taxonomy (DELTA): Available: <http:/ / delta-intkey. com/ >. Accessed: 14th Jul. 2010.

EOL. Encyclopedia of life: http:/ / www.eol.org/ (accessed 14th Jul. 2010).

EDIT. European Distributed Institute of Taxonomy. Available: <www.e-taxonomy.eu $>$. Accessed: 14th Jul. 2010.

Scratchpads: Biodiversity online: $<$ http:/ / scratchpads.eu/>. Accessed: 14th Jul. 2010.

FORZZA, R. C.; et al. Introdução. In: Lista de espécies da flora do Brasil. Jardim Botânico do Rio de Janeiro, 2010.

MAAS, P. J. M.; WESTRA, L. Y. TH. Neotropical plant families. 3. ed. Ruggell: A. R. G. Gantner, 2005.

PBI. Planetary Biodiversity Inventories: <http:// wWw.nsf.gov/funding/pgm_summ.jsp?pims_ id=5343> Accessed: 14th Jul. 2010.

ROSATTI, T. R. The MEKA homepage. <http:/ / ucjeps.berkeley.edu/meacham/meka/index. html>. Accessed 14th Jul. 2010.

WHEELER, Q. D. (Ed.) The New Taxonomy. London: CRC Press, 2008. 237p. (The Systematics Association Special Volume, 76).

WHEELER, Q. D.; RAVEN, P. H.; WILSON, E. O. Taxonomy: impediment or expedient? Science, v. 303, n. 5656, p. 285, 2004.

Recebido em 23/11/10

Aceito para publicação em06/12/10 